\begin{tabular}{|c|c|c|}
\hline & Int.J.Curr.Microbiol.App.Sci (2021) 10(12): 297-303 & \\
\hline & $\begin{array}{l}\text { International Journal of Current Microbiology and Applied Sciences } \\
\text { ISSN: 2319-7706 Volume } 10 \text { Number } 12 \text { (2021) } \\
\text { Journal homepage: http://www.iicmas.com }\end{array}$ & $\$ 0$ \\
\hline $\begin{array}{l}\text { EXCELLENT } \\
\text { PUBLISHERS }\end{array}$ & & \\
\hline
\end{tabular}

\title{
Effect of Slope and Intercropping of Soybean-Maize on Soybean Growth, Yield, Quality and Nutrient Uptake Under Different Slopes in Nagaland
}

\author{
Vizokhonyu Yhome*, Manoj Dutta, R. C. Nayak, Y. K. Sharma \\ and L. Tongpang Longkumer
}

Department of Soil and Water Conservation, School of Agricultural Sciences and Rural Development, Nagaland University, Medziphema Campus-797106

*Corresponding author

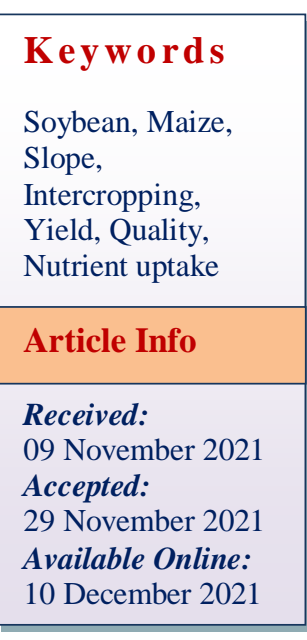

\section{Keywords}

Soybean, Maize,

Slope,

Intercropping,

Yield, Quality,

Nutrient uptake

Article Info

Received:

09 November 2021

Accepted:

Available Online:

10 December 2021

\section{A B S T R A C T}

Field experiment was conducted in the experimental research farm of the School of Agricultural Sciences and Rural Development (SASRD), Medziphema Campus, Nagaland University during the kharif season of 2016 and 2017 to study the effect of slope and intercropping of Soybean-Maize on Soybean growth, yield and nutrient uptake under different slopes in Nagaland. The experiment was laid out in strip plot design with three replications in which the slope was considered as main plot and intercropping as sub-plot. Under the different cropping systems, sole crop performed better than other cropping systems in respect of growth and yield attributing characters. And on intercropping systems i.e., paired rows, soybean + maize (1:1) ratio performed significantly better in terms of yield. The data revealed that the pods/plant, filled pods/plant and seeds/pod were found to be highest in $0 \%$ slope $\left(S_{1}\right)$ which was followed by $9 \%$ slope $\left(S_{2}\right)$ and then $20 \%$ slope $\left(\mathrm{S}_{3}\right)$. The quality of soybean in respect of oil and protein were found to be highest in $9 \%$ slope $\left(\mathrm{S}_{2}\right)$ and $0 \%$ slope $\left(\mathrm{S}_{1}\right)$. The highest $\mathrm{N}, \mathrm{P}$ and $\mathrm{K}$ uptake of the crop were recorded in $0 \%$ slope $\left(\mathrm{S}_{2}\right)$ and sole soybean $\left(\mathrm{T}_{2}\right)$, whereas the lowest was in $20 \%$ slope $\left(\mathrm{S}_{3}\right)$ and soybean + maize $(1: 2)\left[\mathrm{T}_{6}\right]$.

\section{Introduction}

Soybean (Glycine $\max$ L.) is a potential oilseed crop of India native to North Eastern China and is also known as the Golden bean of the $20^{\text {th }}$ century. Soybean is established as premier oilseed crop covering an area of 9.3 million ha with the production of 10.47 metric tonnes in India. In NEH Region, its productivity is $1000 \mathrm{~kg} \mathrm{ha}^{-1}$, which is much higher than the national productivity level $\left(822 \mathrm{~kg} \mathrm{ha}^{-1}\right)$. It is grown as a sole crop as well as intercropped with cereals, pulses, vegetables etc. The cultivated area, production and an average productivity of soybean for the year 2019-20 under Nagaland area was 25170 
ha, 31770 tonnes and $1,262.22 \mathrm{~kg} \mathrm{ha}^{-1}$ respectively (Anonymous, 2020). It is considered as one of the most popular food items among the Naga tribes and is taken as pulse crop as well as fermented product locally called as 'Akhuni' or 'Dacie'. It is rich in high quality protein $(40-45 \%)$, edible oil (18- 20\%) and other nutrients like calcium, iron and glycine. As it meets the different nutritional needs of human being, it can help to overcome the problem of malnutrition in hilly and backward areas. It is also a good source of isoflavones and therefore it helps in preventing heart diseases, cancer and HIVs (Kumar, 2007). Because of the aforementioned qualities, soybean is also termed as "miracle bean", "poor man's meat" and the "powerhouse of protein". It has contributed towards supporting the national economy and meeting the edible oil requirement of the nation in the past four decades. It is an excellent food for children, elderly people and pregnant and lactating women. Besides, being a healthy nutrition for general mass, soy protein is a proven cholesterol-lowering agent. It is kidney friendly and causes calcium to be better utilized to avoid the condition of osteoporosis (Basu et al., 2006). The per capita consumption of the vegetable oil is increasing very rapidly, reaching to approximate $12.6 \mathrm{~kg}$ year $^{-1}$ in comparison to that of $4 \mathrm{~kg}$ year $^{-1}$ in 1961 and the projected demand for the year 2020 is expected to reach $16.38 \mathrm{~kg}_{\text {year }}{ }^{-1}$, respectively. To meeting the need of future burgeoning population it will be requiring nearly 18.3 and 21.8 million tons of edible oil and the major share is to be meet from the soybean. It also builds up the soil fertility by fixing large amount of atmospheric nitrogen through the root's nodules and also through leaf fall on the ground at maturity. Soybean is the main oil crop grown in Nagaland and intercropping with maize is one of the most common soil conservation method practiced by the Nagas. Thus, the present study was initiated to evaluate the effect of intercropping of soybean-maize on soybean growth, yield and nutrient uptake under different slopes in Nagaland.

\section{Materials and Methods}

The field experiment was conducted during kharif season of 2016 and 2017 at SASRD research farm. The research site is located at $25^{\circ} 45^{\prime} 43^{\prime \prime}$ North latitude and $93^{\circ} 53^{\prime} 04^{\prime \prime}$ East longitude with an altitude of 310 meters. The climate of the experimental site is sub-humid tropical with high humidity, moderate temperature and receives medium to high rainfall. Monsoon starts from the first week of June and extends to September and the rains gradually decrease from October. The dry period occurs from November to March.

The average rainfall ranges between 2000$2500 \mathrm{~mm}$. The mean temperature ranges from $21^{\circ}$ to $32^{\circ} \mathrm{C}$ during summer and rarely goes below $8^{\circ} \mathrm{C}$ in the winter season. The experiment was laid out in strip plot design with three replications in which the slope $\left(S_{1}\right.$, $\mathrm{S}_{2}$ and $\mathrm{S}_{3}$ ) was considered as main plot and intercropping $\left(\mathrm{T}_{1}, \mathrm{~T}_{2}, \mathrm{~T}_{3}, \mathrm{~T}_{4}, \mathrm{~T}_{5}\right.$ and $\left.\mathrm{T}_{6}\right)$ as sub-plot. Soybean and Maize were sown in last week of June in both the years. Agronomic management practices were followed as per standard suggestion and growth data were taken at 30 days interval throughout the crop growing season. Yield attributes were recorded at harvest. Seed and straw samples were analyzed for nitrogen by modified Kjeldahl's method (Jackson, 1973), phosphorus by di-acid digestion and yellow colour development method (Jackson, 1973) and potassium by flame photometric method (Jackson, 1973). The nutrient uptake was further calculated by multiplying the nutrient concentration values with the yield data. The data were statistically analyzed using standard procedures of ANOVA at 5\% level of significance. 


\section{Results and Discussion}

\section{Crop growth and yield attributes}

The effect of slope on yield attributes as is evident from Table 1 was observed to be higher at $0 \%$ slope. The number of pods/plant though higher at $0 \%$ slope was comparable to the rest of the main treatments. The same was observed in the case of number of filled pods/plant for both the years. The number of seeds/pod was also not significantly affected by the varying degrees of slope.

Except for the control plots and sole maize cropped plots where soybean was not planted, neither of the yield attributes was affected significantly by the intercropping treatments. The lower number of soybean pods/plant obtained in intercrop could be due to shading and competitive effect by the taller maize as reported by Dalai (1977). Yield reduction in intercrop was related to reduce the number of pods/plant because number of pods significantly influences yield (Akanda and Quayyaum, 1982).

Data pertaining to yield as presented in Table 1 showed better yields at $0 \%$ slope compared to the rest of the treatments. Treatments at $0 \%$ slope gave higher yields during both years. The higher yield can be attributed to better growing conditions as compared to steeper gradients and more nutrients as there was minimal loss of top soil and equal distribution of sunlight.

Among the various intercropping ratios followed, sole soybean gave the highest yield for both years irrespective of slope. Sole soybean recorded the highest seed yield since it suffered from inter specific competition in the intercropping treatment. Similar results were reported by Sawargi and Tripathi (1999) in rice and soybean intercropping system.
Mouneke et al., (2007) also reported higher seed yield of soybean in sole cropping than intercropping with cereals. This can be attributed to lesser competition. In the case of intercropping the growth as well as yield attributes may have been reduced due to competition from maize, as maize is a tall plant which may have induced shading effect on soybean plants resulting in lesser productivity. When the crop with large canopy intercropped with the small crops, such as maize and soybean intercropping, soybean yield could decrease due to interspecific light competition (Liu et al., 2017).

\section{Quality attributes}

Data pertaining to the oil and protein of soybean is presented in Table 2. The variations were not found to vary much due to slope. Oil and protein content were not affected significantly due to variations in slope.

Among the different intercropping methods, sole soybean was observed to record higher values than the rest of the treatments. The variations were however not wide in all the cases. The higher values can be attributed to lesser competition as compared to the other intercropped treatments where maize plant and its roots may have reduced the availability for uptake. Keeping aside the control treatment and sole maize treatment, the content of protein and oil were comparable to each other.

Protein synthesis in soybean is reported to be highly influenced by minerals such as phosphorous, potassium, nitrogen and sulphur (Utsumi et al., 2002; Mahmoodi et al., 2013). However, in this case, apart from sole maize and control plot where no crop was sown, the difference in the content of oil or protein among the treatments was comparable to each other. 
Table.1 Effect of slope and intercropping on number of pods/plant, filled pods/plant, seeds/pod and grain yield of soybean

\begin{tabular}{|c|c|c|c|c|c|c|c|c|}
\hline \multirow[t]{2}{*}{ Treatments } & \multicolumn{2}{|c|}{$\begin{array}{l}\text { Number of } \\
\text { pods/plant }\end{array}$} & \multicolumn{2}{|c|}{$\begin{array}{c}\text { Number of filled } \\
\text { pods/plant }\end{array}$} & \multicolumn{2}{|c|}{$\begin{array}{l}\text { Number of } \\
\text { seeds/pod }\end{array}$} & \multicolumn{2}{|c|}{$\begin{array}{l}\text { Grain yield } \\
\left(\mathrm{kg} \mathrm{ha}^{-1}\right)\end{array}$} \\
\hline & 2016 & 2017 & 2016 & 2017 & 2016 & 2017 & 2016 & 2017 \\
\hline \multicolumn{9}{|l|}{ Slope } \\
\hline$S_{1}(0)$ & 58.29 & 56.87 & 57.07 & 55.53 & 2.00 & 1.98 & 1078.6 & 1060.0 \\
\hline $\mathbf{S}_{2}(\mathbf{9})$ & 54.23 & 52.82 & 52.95 & 51.48 & 2.00 & 1.98 & 960.0 & 926.7 \\
\hline$S_{3}(20)$ & 52.79 & 51.46 & 51.52 & 49.57 & 2.04 & 2.00 & 925.5 & 892.2 \\
\hline Sem \pm & 1.85 & 1.63 & 1.67 & 1.62 & 0.02 & 0.02 & 29.86 & 34.5 \\
\hline CD at $5 \%$ & NS & NS & NS & NS & NS & NS & 117.2 & 135.6 \\
\hline \multicolumn{9}{|l|}{ Crop } \\
\hline$T_{1}$ - Control & 0.00 & 0.00 & 0.00 & 0.00 & 0.00 & 0.00 & 0.00 & 0.00 \\
\hline $\mathbf{T}_{2}$ - Sole Soybean & 85.35 & 83.11 & 84.69 & 80.78 & 3.11 & 3.00 & 1610.0 & 1560.0 \\
\hline$T_{3}$ - Sole Maize & 0.00 & 0.00 & 0.00 & 0.00 & 0.00 & 0.00 & 0.00 & 0.00 \\
\hline $\begin{array}{l}T_{4}-\text { Soybean } \\
+ \text { Maize }(1: 1)\end{array}$ & 83.77 & 81.64 & 81.44 & 79.42 & 3.00 & 3.00 & 1476.6 & 1426.7 \\
\hline $\begin{array}{l}T_{5}-\text { Soybean } \\
+ \text { Maize }(2: 1)\end{array}$ & 81.59 & 79.90 & 79.25 & 77.57 & 3.00 & 3.00 & 1492.2 & 1440.0 \\
\hline $\begin{array}{l}T_{6}-\text { Soybean } \\
+ \text { Maize }(1: 2)\end{array}$ & 79.92 & 77.63 & 77.70 & 75.41 & 2.96 & 2.93 & 1349.4 & 1297.8 \\
\hline Sem \pm & 1.82 & 2.51 & 1.96 & 2.04 & 0.03 & 0.06 & 40.5 & 36.75 \\
\hline CD at $5 \%$ & 5.72 & 7.91 & 6.73 & 7.31 & 0.09 & 0.18 & 127.8 & 115.8 \\
\hline
\end{tabular}

Note: No crops grown in $\mathrm{T}_{1}-$ Control; No soybean grown in $\mathrm{T}_{3}-$ Sole Maize

Table.2 Effect of slope and intercropping on oil and protein content of soybean

\begin{tabular}{|c|c|c|c|c|}
\hline \multirow{2}{*}{ Treatments } & \multicolumn{2}{|c|}{ Oil content (\%) } & \multicolumn{2}{c|}{ Protein content (\%) } \\
\cline { 2 - 5 } & $\mathbf{2 0 1 6}$ & $\mathbf{2 0 1 7}$ & $\mathbf{2 0 1 6}$ & $\mathbf{2 0 1 7}$ \\
\hline Slope & & & & \\
\hline $\mathbf{S}_{\mathbf{1}}(\mathbf{0})$ & 11.28 & 11.17 & 23.83 & 24.00 \\
\hline $\mathbf{S}_{\mathbf{2}}(\mathbf{9})$ & 11.50 & 11.78 & 23.94 & 23.94 \\
\hline $\mathbf{S}_{\mathbf{3}}(\mathbf{2 0})$ & 11.39 & 11.61 & 23.83 & 23.83 \\
\hline Sem \pm & 0.29 & 0.16 & 0.13 & 0.15 \\
\hline CD at 5\% & $\mathrm{NS}$ & $\mathrm{NS}$ & $\mathrm{NS}$ & $\mathrm{NS}$ \\
\hline Crop & & & & \\
\hline $\mathbf{T}_{\mathbf{1}}-\mathbf{C o n t r o l}$ & 0.00 & 0.00 & 0.00 & 0.00 \\
\hline $\mathbf{T}_{\mathbf{2}}$ - Sole Soybean & 17.33 & 17.67 & 36.11 & 36.11 \\
\hline $\mathbf{T}_{\mathbf{3}}-$ Sole Maize & 0.00 & 0.00 & 0.00 & 0.00 \\
\hline $\mathbf{T}_{\mathbf{4}}-$ Soybean +Maize (1:1) & 16.89 & 17.22 & 35.33 & 35.56 \\
\hline $\mathbf{T}_{\mathbf{5}}$ - Soybean +Maize (2:1) & 17.11 & 17.11 & 35.78 & 35.89 \\
\hline $\mathbf{T}_{\mathbf{6}}-$ Soybean +Maize (1:2) & 17.00 & 17.11 & 36.00 & 36.00 \\
\hline Sem \pm & 0.31 & 0.22 & 0.13 & 0.24 \\
\hline CD at 5\% & 0.98 & 0.70 & 0.41 & 0.75 \\
\hline
\end{tabular}

Note: No crops grown in $\mathrm{T}_{1}-$ Control; No soybean grown in $\mathrm{T}_{3}-$ Sole Maize 
Table.3 Effect of slope and intercropping on uptake of N, P and K by soybean

\begin{tabular}{|c|c|c|c|c|c|c|}
\hline \multirow[t]{2}{*}{ Treatments } & \multicolumn{2}{|c|}{$\begin{array}{c}\text { N uptake } \\
\left(\mathrm{kg} \mathrm{ha}^{1}\right)\end{array}$} & \multicolumn{2}{|c|}{$\begin{array}{c}\text { P uptake } \\
\left(\mathrm{kg} \mathrm{ha}^{1}\right)\end{array}$} & \multicolumn{2}{|c|}{$\begin{array}{c}\text { K uptake } \\
\left(\mathrm{kg} \mathrm{ha}^{1}\right)\end{array}$} \\
\hline & 2016 & 2017 & 2016 & 2017 & 2016 & 2017 \\
\hline \multicolumn{7}{|l|}{ Slope } \\
\hline$S_{1}(0)$ & 36.18 & 34.96 & 3.50 & 3.31 & 22.30 & 21.61 \\
\hline$S_{2}(9)$ & 32.03 & 30.92 & 3.19 & 3.03 & 20.73 & 19.93 \\
\hline$S_{3}(20)$ & 31.18 & 29.90 & 3.05 & 2.88 & 19.83 & 19.04 \\
\hline $\operatorname{Sem} \pm$ & 1.17 & 1.27 & 0.11 & 0.11 & 0.67 & 0.76 \\
\hline CD at $5 \%$ & 4.61 & 4.98 & 0.45 & 0.44 & 2.64 & 2.98 \\
\hline \multicolumn{7}{|l|}{ Crop } \\
\hline$T_{1}$ - Control & 0.00 & 0.00 & 0.00 & 0.00 & 0.00 & 0.00 \\
\hline$T_{2}$ - Sole Soybean & 52.51 & 50.43 & 5.10 & 4.79 & 32.68 & 31.21 \\
\hline$T_{3}$ - Sole Maize & 0.00 & 0.00 & 0.00 & 0.00 & 0.00 & 0.00 \\
\hline$T_{4}-$ Soybean +Maize $(1: 1)$ & 49.83 & 48.12 & 4.81 & 4.56 & 31.29 & 30.39 \\
\hline $\mathrm{T}_{5}-$ Soybean +Maize (2:1) & 49.03 & 47.29 & 4.92 & 4.65 & 31.50 & 30.39 \\
\hline$T_{6}$ - Soybean +Maize (1:2) & 47.41 & 45.72 & 4.63 & 4.44 & 30.25 & 29.15 \\
\hline Sem \pm & 1.48 & 1.59 & 0.15 & 0.13 & 0.95 & 0.82 \\
\hline CD at $5 \%$ & 4.66 & 5.01 & 0.47 & 0.41 & 3.01 & 2.59 \\
\hline
\end{tabular}

Note: No crops grown in $\mathrm{T}_{1}-$ Control; No soybean grown in $\mathrm{T}_{3}$ - Sole Maize

\section{Nutrients uptake}

The data on $\mathrm{N}$ uptake under different slopes varied from $31.18 \mathrm{~kg} \mathrm{ha}^{-1}$ to $36.18 \mathrm{~kg} \mathrm{ha}^{-1}$ in the year 2016 and $29.90 \mathrm{~kg} \mathrm{ha}^{-1}$ to $34.96 \mathrm{~kg}$ $\mathrm{ha}^{-1}$ in the year 2017 (Table 3). The highest $\mathrm{N}$ uptake was recorded in $0 \%$ slope $\left(\mathrm{S}_{1}\right)$ in both the years recording 36.18 and $34.96 \mathrm{~kg} \mathrm{ha}^{-1}$ followed by $9 \%$ slope $\left(\mathrm{S}_{2}\right)$ during 2016 and 2017, respectively. The lowest $\mathrm{N}$ uptake was recorded in $20 \%$ slope $\left(\mathrm{S}_{3}\right)$ with a value of 31.18 and $29.90 \mathrm{~kg} \mathrm{ha}^{-1}$ during 2016 and 2017 , respectively.

The effect of different slope percentage on $\mathrm{P}$ uptake of soil presented in Table 3 revealed that the highest $P$ uptake i.e. 3.50 and $3.31 \mathrm{~kg}$ $\mathrm{ha}^{-1}$ were recorded in 0\% slope $\left(\mathrm{S}_{1}\right)$ in 2016 and 2017, respectively. And the lowest $\mathrm{P}$ uptake (3.05 and $2.88 \mathrm{~kg} \mathrm{ha}^{-1}$ ) were found in $20 \%\left(\mathrm{~S}_{3}\right)$ during 2016 and 2017. While the data pertaining to the $\mathrm{K}$ uptake presented in Table 3 under different slope percentage pointed that the highest $\mathrm{K}$ uptake was noted in $0 \%$ slope $\left(S_{1}\right)$ with a value of 22.30 and 21.61 $\mathrm{kg} \mathrm{ha}^{-1}$ in both the experimental years. The lowest was recorded in $20 \%$ slope $\left(S_{3}\right)$ with a value of 19.83 and $19.04 \mathrm{~kg} \mathrm{ha}^{-1}$. Perusal of Table 3 revealed that variations in slope had significant effect on the uptake of nutrients. $0 \%$ slope recorded significantly higher values of $\mathrm{N}, \mathrm{P}$ and $\mathrm{K}$ uptake followed by $9 \%$ and $20 \%$ slope respectively. The uptake of nutrients had a negative correlation with the degree of slope. Though there were slight variations in the nutrient content, the significant differences in uptake were a result of the differences in biomass and not because of the concentration.

Among the various intercropping systems, the highest $\mathrm{N}$ uptake i.e. 52.51 and $50.43 \mathrm{~kg} \mathrm{ha}^{-1}$ were recorded in sole soybean treatment in 2016 and 2017, respectively followed by soybean + maize $(1: 1)\left(\mathrm{T}_{4}\right)$. The lowest $\mathrm{N}$ uptake were found in soybean + maize (1:2) 
( $\left.\mathrm{T}_{6}\right)$ during 2016 and 2017 respectively. The $\mathrm{P}$ uptake in the soil after various cropping pattern ranged from 4.63 to $5.10 \mathrm{~kg} \mathrm{ha}^{-1}$ and 4.44 to $4.79 \mathrm{~kg} \mathrm{ha}^{-1}$ in 2016 and 2017 , respectively. In both the years of the experiment the highest $\mathrm{P}$ uptake was found in sole soybean $\left(\mathrm{T}_{2}\right)$ followed by soybean + maize $(2: 1)\left(\mathrm{T}_{5}\right)$ and the lowest was observed in soybean + maize $(1: 2)\left(\mathrm{T}_{6}\right)$ sole maize. Data on different intercropping system on $\mathrm{K}$ uptake revealed that, the maximum value was found under sole soybean $\left(\mathrm{T}_{2}\right)$ during 2016 and 2017 respectively, with a value of 32.68 and 31.21 $\mathrm{kg}$ ha-1, which was followed by control $\left(\mathrm{T}_{5}\right)$ treatment during both the experimental years. However, the minimum $\mathrm{K}$ uptake of 30.25 and $29.15 \mathrm{~kg} \mathrm{ha}^{-1}$ was recorded under soybean + maize $(1: 2)\left(\mathrm{T}_{6}\right)$ and soybean + maize $\left(\mathrm{T}_{4}\right)$ during 2016 and 2017, respectively.

Among the sub-treatments, sole soybean recorded higher values of $\mathrm{N}, \mathrm{P}$ and $\mathrm{K}$ uptake compared to the intercropped treatments. $\mathrm{Li}$ Long et al., (2001) also reported that nutrient acquisitions by intercrops were significantly greater when intercropped than when grown as sole crops. The variations in this regard can also be attributed to the differences in biomass production and not in the variations in nutrient concentration.

\section{References}

Akanda, M. E. and Quayyaum, M. A. 1982. Effect of intercropping soybean, mungbean, black gram and groundnut with maize. Bangladesh Journal of Agriculture Science. 84: 71-78.

Anonymous. 2020. Directorate of Economics and Statistics, Govt. of Nagaland, Nagaland Statistical Handbook. 31.

Basu, D., Francis, Kuliran. and Roy, B. D. 2006. Agriculture, food security, nutrition and health in North East India. Mittal Publication, New Delhi.

Dalai, R. C. 1977. Effect of intercropping maize with soybean on grain yield. Tropical Agriculture (Trinidad). 54(2): 189-191.

Jackson, M. L. 1973. Soil Chemical Analysis, Prentice Hall of India Pvt. Ltd., New Delhi.

Kumar, A. 2007. A study of consumer attitudes and acceptability of soy food in Ludhiana. MBA research project report, Department of Business Management, Punjab Agricultural University, Ludhiana, Punjab.

Li, Long., Sun, Jianhao., Zhang, Fusuo., Li, Xiaolin., Yang, Sicun. and Rengel, Zdenko. 2001. Wheat/Maize or Wheat/Soybean strip intercropping I. Yield advantage and interspecific interactions on nutrients. Field Crops Research. 71.

Liu, X., Rahman, T., Song, C., Su, B., Yang, F., Yong, T. and Yang, W. 2017. Changes in light environment, morphology, growth, and yield of soybean in maize-soybean intercropping systems. Field Crops Research. 200: 38-46.

Mahmoudi, Robab., Jamshidi, Khalil. and Pouryousef, Majid. 2013. Evaluation of grain yield of maize (Zea mays L.) and soybean (Glycine max (L.) Merill) in strip intercropping. International Journal of Agronomy and Plant Production. 4(9): 2399-2392.

Mouneke, C. O., Ogwuche, M. A. O. and Kalu, B. A. 2007. Effect of maize planting density on the performance of maize/soybean intercropping system in a guinea savannah agro-ecosystem. African Journal of Agricultural Research. 2(12): 667-77.

Sawargi, S. K. and Tripathi, R. S. 1999. Planting geometry and nitrogen management in rice (Oryza sativa) and soybean (Glycine max) intercropping. Indian Journal of Agronomy. 44(4): 681-687. 
Utsumi, S., Maruyama, N. and Satoh, R. 2002. Structure function relation of soybean protein revealed by using recombinant systems. Enzyme and Microbial Technology. 30: 284-288.

\section{How to cite this article:}

Vizokhonyü Yhome, Manoj Dutta, R. C. Nayak, Y. K. Sharma and Tongpang Longkumer, L. 2021. Effect of Slope and Intercropping of Soybean-Maize on Soybean Growth, Yield, Quality and Nutrient Uptake Under Different Slopes in Nagaland. Int.J.Curr.Microbiol.App.Sci. 10(12): 297-303. doi: https://doi.org/10.20546/ijcmas.2021.1012.034 